\title{
THE PREVALENCE OF STUNTING, POVERTY, AND ECONOMIC GROWTH IN INDONESIA: A DYNAMIC PANEL DATA CAUSALITY ANALYSIS
}

\author{
Andi Kustanto*1 (iD \\ ${ }^{1}$ Department of Economics, Universitas Sultan Ageng Tirtayasa, Indonesia
}

\begin{abstract}
In recent years, policy discussions and debates have emphasised the efficiency of development policies to translate economic growth into sustainable economic development. One of the main aspects in this regard is achieving improvement in child nutrition through economic development. Nevertheless, there is a scarcity of literature that empirically verifies the causality between stunting, poverty, and economic growth in 34 provinces in Indonesia using Klassen's typology analysis and Panel VECM. This study indicates that the prevalence of stunting has a direct causality towards poverty and economic growth in the long-term by $0.02 \%$. Handling high the prevalence of stunting needs to be focused on in all provinces in Indonesia. Poverty directly affects the stunting prevalence and economic growth in the long-term by $0.06 \%$. The percentage of the population, poverty outside Java, including Nusa Tenggara, Moluccas, and Papua, is also higher than in Java. Therefore, efforts to tackle poverty should be more focused on these areas. Economic growth has a direct causality to the prevalence of stunting and poverty by $0.57 \%$. It proves that the country's economic growth is accompanied by socioeconomic development and improving the poor's livelihoods and welfare. Can also recommend specific nutrition and sensitive nutrition interventions to impact the massive reduction of stunting in Indonesia.
\end{abstract}

\section{ARTICLE INFO}

Received: September $30^{\text {th }}, 2020$

Revised: April 1 ${ }^{\text {st }}, 2021$

Accepted: May $8^{\text {th }}, 2021$

Online: November $25^{\text {th }}, 2021$

*Correspondence: Andi Kustanto

E-mail:

andikustanto@outlook.com

Keywords: Stunting, Poverty, Economic Growth, Indonesia

JEL: I10; I18; I32; 010; 015; P36

To cite this document: Kustanto, Andi. (2021). The Prevalence of Stunting, Poverty, and Economic Growth in Indonesia: A Panel Data Dynamic Causality Analysis. JDE (Journal of Developing Economies), Vol. 6(2), 150-173

\section{Introduction}

Malnutrition problem is still commonly found in various community groups in several developing countries, especially Indonesia. One of the problems of malnutrition that needs attention is stunting. Malnutrition problems, especially stunting prevalence in children under five years old, can hamper development at a young age with negative impacts on subsequent life (UNICEF, 2018).

Stunting is a growth and development disorder experienced by toddlers suffering from malnutrition, recurrent infections, and inadequate psychosocial stimulation as indicated by 
the height z-score by age <-2 standard deviations based on the WHO Child Growth Standards median (WHO, 2014a). Stunting in children under five is one of the most significant obstacles to human growth and development, which globally has affected 162 million children under five years of age (WHO, 2014b). The most irreversible result of inadequate nutrition and recurrent attacks of infection at the period of the first 1,000 days of a child (Madan et al., 2018; Hoddinott et al., 2013).

The risk factors for stunting include pregnant women's nutritional status on the fetus's growth and development, which must consider nutritional problems since they are still in the womb (Sukmawati et al., 2018; Alfarisi et al., 2019). The causes vary, for example, due to low access to nutritious food, low intake of vitamins and minerals, and reduced diversity of food and animal protein sources (Mayneris \& Jonathan, 2018). A lack of nutritional status in early life will impact the next life, such as the fetus's stunted growth, low birth weight, small, short, thin, low endurance, and the risk of death (Zaif et al., 2017).

Stunting has long-term effects on individuals and society, including reduced cognitive and physical development, decreased productive capacity and poor health, and an increased risk of degenerative diseases such as diabetes (Grantham-McGregor et al., 2007; UNICEF, 2018; TNP2K, 2018; Casale et al., 2018; Uwiringiyima et al., 2019). The magnitude of the problem of stunting in children today will impact the quality of the nation's future. If this trend continues, projections show that 127 million children will be restricted from growing to under five years of age by 2025 .

Globally the number of children stunted is 150.8 million or $22.2 \%$ (UNICEF, 2018). Asia is the second region after Africa which has the highest prevalence of stunting in the world, and Indonesia is one of the countries in Southeast Asia that has the fifth-highest stunting prevalence in the world by $37 \%$, or nearly 9 million children who have stunted according to Indonesia Basic Health Research.

Based on the Indonesia Basic Health Research 2018 results, $17.7 \%$ of infants under five years old (toddlers) were still experiencing nutritional problems. Figure 1 consists of toddlers experiencing severe malnutrition of $3.9 \%$ and those suffering from $13.8 \%$. Compared to the Indonesia Basic Health Research, infants who experience nutritional problems go down, as shown in the graph below.

In the National Medium-Term Development Plan 2015-2019, infants are experiencing nutritional problems that fall to $17 \%$. The prevalence of stunted toddlers (below standard height according to age) is $27.67 \%$, down compared to the Indonesia Basic Health Research results, which was $37.2 \%$. Although there has been a decrease in stunting prevalence from $37.2 \%$ in 2013 to $27.67 \%$ in 2019 , the stunting prevalence rate is still relatively high because almost one in three Indonesian children under five is stunting.

Stunting can hamper economic growth and labour productivity. Evidence shown includes the loss of $11 \%$ of GDP and reducing adult workers' income by up to $20 \%$. Stunting also exacerbates inequalities that cause a $10 \%$ reduction in total lifetime income and give rise to intergeneration (World Bank, 2016). WHO made stunting the focus of the Global Nutrition Targets 2025 and the 2030 agenda for Sustainable Development Goals, so preventing stunting is crucial to achieving quality Indonesian human resources and equitable economic growth and breaking the intergenerational poverty chain.

Economic growth is a critical indicator in conducting development analysis and mea- 
suring the development of an economy (Kustanto, 2020). The high prevalence of stunting and its relationship to economic growth in several developing countries is a heated debate among experts (Mary, 2018; Biadgilign et al., 2016; O'Connell \& Smith, 2016; Smith \& Haddad, 2015; Ruel \& Alderman, 2013).

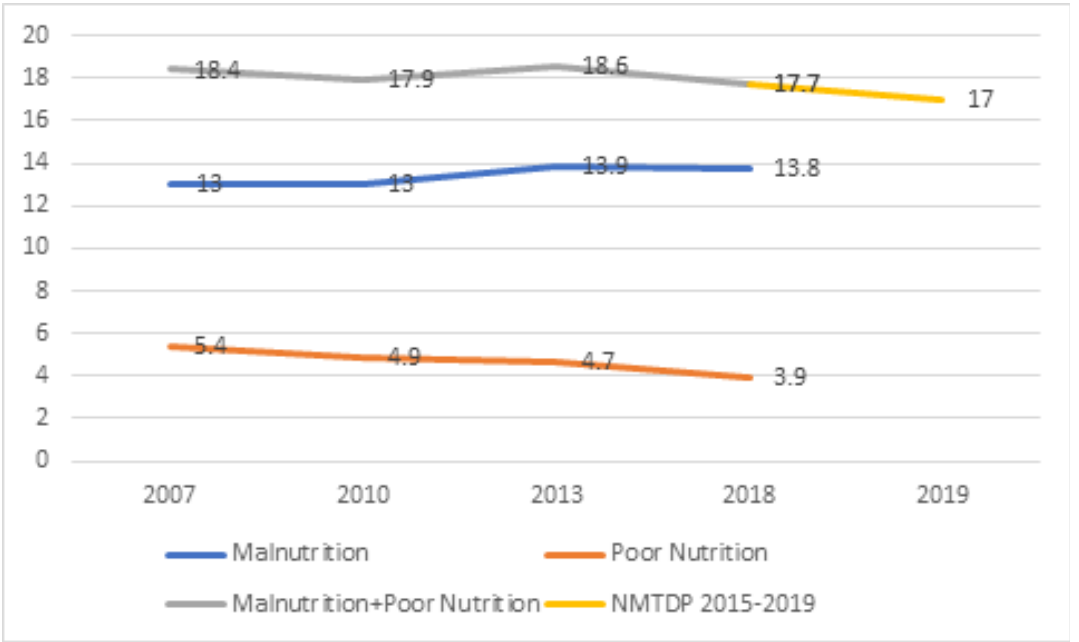

Source: Ministry of Health, Author's Calculation

Figure 1: The proportion of Children with Nutrition Problems (2007-2019)

The debate from these experts has a significant impact on strategic economic growth that is more pro-poor, vulnerable and reduces cases of children under-five who are malnourished and the need to invest in complementary nutrition directly. With that expansion, these various types of investments can affect a person's limited financial resources to be allocated competitively.

The relationship between increasing economic growth and improving nutritional status are two equal things. When economic growth increases, people can spend most of their income on consuming goods and services related to health and nutrition fulfilment.

Increased incomes have also encouraged the availability of services for the community in health infrastructure because it can allocate government spending more for investment in health infrastructure provision. However, such links may be weaker than expected. For example, if economic growth is associated with an increase in income inequality, the poorest may not benefit from increasing national income.

This study is intended to determine the type and direction of the relationship between stunting, poverty, and economic growth in Indonesia during 2010-2018. The relationship between stunting, poverty, and economic growth can be the basis for policy decision-makers in economic development.

Klassen's typology analysis will be used in this study to provide an overview and structure of stunting, poverty, and economic growth. This study will be known by using maps in 34 provinces in Indonesia that need to be prioritised in poverty reduction and stunting reduction. Besides, this study will be tested with the Granger Causality method with the VAR/VECM model to investigate this. The VECM model is used when there is cointegration in the relationship between the variables. Cointegration will be analysed using Kao (Engle-Granger-based) Cointegration Tests.

In the Indonesian context, this study contributes to the existence of the literature in several ways. First, this study shows a causal relationship between stunting, poverty, and eco- 
nomic growth. These findings will reveal a significant contribution to the government and related institutions. Second, stunting is closely related to poverty. These findings will inform that poverty impacts people's access to meet food needs and maternal and infant health services. Third, this study will show evidence of targeted causality of stunting, poverty, and economic growth in the long term.

\section{Literature Review}

Various empirical studies have provided different estimates that contribute to the lack of consensus. For example, a study conducted (Mary, 2018; de Onis \& Branca, 2016) argues that economic growth has influenced the reduction in stunting prevalence. The impact of the double burden of malnutrition is not only felt by individuals. Barker (2007) argues that this double burden of malnutrition has a common cause, inadequate nutrition of fetuses and infants and young children followed by exposure to unhealthy energy, low nutrient-dense nutrient foods, and lack of physical activity.

A study in South Africa shows that the dual burden of nutrition-related illnesses and the vicious cycle of poverty argues for nutrition interventions in poverty alleviation programs (Vorster 2010). From history (Horrell et al., 2001) and also presents data analysis from developing countries (Dao, 2008) explaining that only an increase in human capital through interventions in health, nutrition, and education will lead to increased productivity and hence income to lift people out of poverty.

In Indonesia, the economy is also affected; losses due to stunting and malnutrition are estimated to be equivalent to $2-3 \%$ of Indonesia's GDP. Indonesia is still in fifth place as the country with the completion of stunting. Children with chronic malnutrition in Indonesia have reached 30\% (Titaley et al., 2019). More and more non-communicable diseases in Indonesia have resulted in increased spending for the government, especially for national health insurance.

Children are a golden age for child development. A study conducted by Worku et al. (2018) recently about malnutrition in extreme poverty in Ethiopia found that among $819 \mathrm{im}$ poverished children, 325 people (39.7\%) experienced stunting, 135 people (16.5\%) were underweight, and 27 people (3.3\%) experience wasted. They are stunting results from a complex interaction of household, environmental, socioeconomic, and cultural influences described in the WHO Conceptual Framework on Childhood Stunting (Stewart et al., 2013).

Bata et al. (2017) argue that stunting correlates with many of the long-term consequences of life, including reduced cognitive development and higher morbidity and mortality levels, and makes stunting a significant contributor to poverty. Studies in Bangladesh show a link between poverty and malnutrition found in illiterate mothers, low household income, having more siblings, having access to lower media, poor nutrition, and sanitation and health lower environment (Khan \& Kraemer, 2009).

The incidence of stunting in toddlers can cause IQ disorders. Stunted children had an average IQ of 11 points lower than the non-stunting average (UNICEF, 2009). Also, stunting can increase the risk of obesity and overweight. If this situation continues to be allowed, there can be an increased risk of degenerative diseases (Anugraheni \& Kartsurya, 2012). The results of the literature review conducted by Vilcins et al. (2018) of 71 reports, in the final analysis, show that various environmental risk factors, at multiple levels, are related to stunting and show the importance of considering how the environment interacts with nutrition. 
The environmental risk factors in this study all consisted of an 'unhealthy' child environment. Reducing stunting in childhood and maintaining these outcomes in the face of climate change requires interventions to reduce stunting to be comprehensive and integrated into their consideration of the role of environmental risk factors.

Studies carried out in South Africa, India, Panama, Guatemala, and Brazil using longitudinal data show that children who are stunted at the age of two are confirmed to experience delays in attending school or staying in class for one year at school (Martorell et al., 2009; Adair et al., 2013).

The incidence of stunting in children under five years arises due to long-standing conditions such as poverty, improper parenting behaviour, and often suffering from recurrent disease due to clean water quality and poor sanitation. At present, hundreds of people in the world are at risk of global climate change. Global climate change not only impacts climate threats but also because of the most significant consequences and negative impacts on livelihoods and nutritional security (Crahay et al., 2010).

Poverty and malnutrition are two sides of a coin that destroy developing countries. A study conducted by Larrea \& Kawachi (2005) in Ecuador shows that economic inequality at the regional scale has a statistically significant adverse effect on stunting. Olalekan et al. (2017) argue that poverty has become a substantial cause of hunger in Africa. This poverty has been considered dangerous in economic systems, conflicts, environmental factors such as land drought, climate change, and population growth.

Poverty alleviation can resolve with economic growth into social changes that benefit the poor to portray as oriented towards development (Kuada, 2014). Ogundari \& Aromolaran (2017) in their study, showed that the results of the causality test revealed evidence of a longterm and short-term two-way causality relationship between nutrition and economic growth, which implies that increased nutrition is the cause and consequence of economic growth and vice versa in sub-Saharan Africa.

Measured economic growth through per capita income has the main essence of development, namely improving people's standard and quality of life and reducing poverty. The study Jr. (2004) using 126 new data intervals from 60 developing countries, found that the elasticity of poverty growth (excluding Europe and Central Asia) was 2.79; that is, every $10 \%$ increase in the survey carried out would reduce poverty (\$1.00/person/day) by $27.9 \%$. However, when changes in GDP per capita measure growth, poverty growth's elasticity is not statistically significant at 2.27 , which is lower than previously thought.

In a review of the evidence assessing the economic impact of childhood stunting and undernutrition, the results of intervention studies and research using Randomized Control Trials (RCTs) consistently showed substantial financial returns to linear growth and reduction in stunting at the individual level (McGovern et al., 2017).

Economic growth has broadly impacted the eradication of intergenerational poverty and stunted children. Studies conducted by Frimpong et al. (2016) to test children's nutrition in Ghana on economic growth in the 1980s and 1990s showed that stunting declined between 1988 and 1998 and increased significantly. The increase in stunting after 1998 implies that economic growth can lead to a rise in household economic factors not necessarily translated into improvement and nutrition for children. The decline in children's development, explained by the decline in the utilisation of health services after the country's reform of the health care system. 
A study conducted by Rashad \& Sharaf (2018) using repeated cross-sectional data from five rounds of the National Demographic and Health Survey (DHS) found a statistically significant strong negative relationship between economic growth, at the governor level, and four child malnutrition outcomes in Egypt during the period 1992-2008.

Studies using socioeconomic status and demographic factors are associated with malnutrition in children and how these factors contribute to the socioeconomic inequality of child malnutrition carried out (Lyakurwa, 2009; Harttgen et al., 2013; Vollmer et al., 2014). Habibullah et al. (2016) found that economic growth significantly affects intergenerational poverty reduction and children under five years of age who experience stunted growth.

Differences of opinion from experts regarding the relationship between stunting, poverty alleviation, and economic growth are still widely discussed. This difference of opinion also occurs in Indonesia. This study wants to fill the empty spaces regarding the three's causality, whether they influence each other.

Therefore, this study investigates the relationship between stunting, poverty, and economic growth in Indonesia. This study's findings are essential for developing poverty reduction and malnutrition policies in children under five years of age and become an exciting study of literature to be studied as the development of science in the field of development economics.

\section{Data and Research Methods}

This study uses descriptive and quantitative methods. The descriptive method is describing a problem and analysing data and matters relating to calculation or calculation form. Quantitative methods for processing data in this study use Klassen's typology analysis and Vector Error Correction Model (VECM) consisting of 34 provinces in Indonesia in 2010-2018 and then converted to panel data the Central Bureau of Statistics and the Indonesian Health Profile, Ministry of Health.

\section{Klassen's Typology Analysis}

Klassen's typology analysis produced four sector classifications with different characteristics (Hatta \& Astuti, 2018). The description and structure of prevalence of stunting, poor people, and economic growth will be known using the mapping of 34 provinces in Indonesia that need to be given priority for poverty alleviation and high stunting reduction. Klassen's typology analysis used in this study can be written as follows:

Table 1: Analysis of the Klassen Typology Approach Between Prevalence of Stunting and Percentage of Poor People

\begin{tabular}{|c|c|c|}
\hline \multirow[t]{2}{*}{ The Prevalence of Stunting } & \multicolumn{2}{|c|}{ Percentage of Poor People } \\
\hline & Poverty $_{i}>$ Poverty & Poverty $_{i}<$ Poverty \\
\hline Stunting $>$ Stunting & Quadrant I & Quadrant II \\
\hline Stunting $_{i}<$ Stunting & Quadrant III & Quadrant IV \\
\hline
\end{tabular}

Stunting $_{i}$ is the prevalence of stunting in province; Stunting is the average distribution of the prevalence of stunting in 34 provinces in Indonesia; Poverty is the percentage of poverty in province ; Poverty is the average distribution of poverty in 34 provinces in Indonesia; Growth ${ }_{i}$ is the average percentage of economic growth in province; Growth is the average distribution of economic growth in 34 provinces in Indonesia. 
Table 2: Analysis of the Klassen Typology Approach Between Prevalence of Stunting and Economic Growth

\begin{tabular}{ccc}
\hline The Prevalence of Stunting & \multicolumn{2}{c}{ Percentage of Economic Growth } \\
\cline { 2 - 3 } & Growth $_{i}>$ Growth & Growth $_{i}>$ Growth \\
\hline Stunting $>$ Stunting & Quadrant I & Quadrant II \\
\hline Stunting $<$ Stunting & Quadrant III & Quadrant IV \\
\hline
\end{tabular}

Source: Author's, 2020

\section{Vector Error Correction Model (VECM)}

Engle \& Granger (1987) show that although time series data are often not stationary at the level or called non-stationary data, a linear combination between two or more non-stationary data, non-stationary time series data are said to be cointegrated. The Vector Error Correction Model (VECM) approach is used in the nonstructural Vector Autoregression (VAR) model if time series data are not statistically at the level but are stationary at differentiation cointegrated so that there is a theoretical relationship between variables.

This cointegration, the VECM, a nonstructural VAR model, is called the predicted VAR model. The VECM specification restricts the long-term behavioural relationships between variables to converge into cointegration relationships while still allowing dynamic changes in the short term. This cointegration term is known as error correction because if there is a deviation of the long-term balance, it will be corrected gradually through gradual partial shortterm adjustments. The VECM model can be written as follows:

$$
\begin{gathered}
\Delta y_{t}=\alpha e_{t-1}+\beta_{1} \Delta y_{t-1}+\beta_{2} \Delta y_{t-2}+\ldots+\beta_{p} \Delta y_{t-p+1}+\varepsilon_{t} \\
\text { Where, } e_{t-1}=Y_{t-1}-\left(\varphi+\omega X_{t-1}\right)
\end{gathered}
$$

Information, $\Delta y_{t}$ is the first descending vector of the dependent variable, $\Delta y_{t-1}$ is the first derivative vector of the independent variable with lag-1, $e_{t-1}$ is the error obtained from the regression equation between $\mathrm{Y}$ and $\mathrm{X}$ on lag-1 and also called Error Correction Term (ECT), $\varepsilon_{t}$ is the residual vector, $\alpha$ is the cointegration coefficient matrix, $\beta_{i}$ is the dependent variable coefficient matrix $i$, were $1,2, \ldots, p$. The operational model used to analyse the relationship between the prevalence of stunting, the percentage of poor people, and the percentage of economic growth can be written as follows:

$$
\begin{aligned}
\Delta \text { Stunting }_{i t} & =\alpha_{1}+\beta_{1} \Delta \text { Growth }_{i t-1}+\gamma_{1} \Delta \text { Poverty }_{i t-1}+\delta_{1} \text { Stunting }_{i t-1}+E C T_{i t-1}+\varepsilon_{1 i t} \\
\Delta \text { Poverty }_{i t} & =\alpha_{2}+\beta_{2} \Delta \text { Growth }_{i t-1}+\gamma_{2} \Delta \text { Poverty }_{i t-1}+\delta_{2} \text { Stunting }_{i t-1}+E C T_{i t-1}+\varepsilon_{2 i t} \\
\Delta \text { Growth }_{i t} & =\alpha_{2}+\beta_{2} \Delta \text { Growth }_{i t-1}+\gamma_{2} \Delta \text { Poverty }_{i t-1}+\delta_{2} \text { Stunting }_{i t-1}+E C T_{i t-1}+\varepsilon_{2 i t}
\end{aligned}
$$

Stunting is the prevalence of stunting; Poverty is the percentage of poor people; Growth is the percentage of economic growth; is a cross-section of 34 provinces in Indonesia; $t$ is time-series data; $\sigma, b, \gamma, \delta$ are the cointegration coefficients matrix; and $E C T$ is an error obtained from the similarities between the prevalence of stunting, percentage of poor people, and percentage of economic growth in lag-1 and also called the Error Correction Term (ECT). Analysis of the long-term causality relationship between the independent variable and the dependent variable in VECM modelling can be seen in the coefficient of the error correction term (ECT), which is based on the sign and the results of the coefficient significance test using the t-Test statistic in the Ordinary Least Square (OLS) method.

Theoretically, the forecasting and structural analysis of VECM has similarities with the forecast analysis and structural analysis of the VAR model. In VAR modelling, the analysis 
can use impulse response analysis and variance decomposition (Lütkepohl, 2006; Lütkepohl, 2011). Impulse Response Function (IRF) analysis aims to see the effect (influence) of each variable (endogenous) if a shock or impulse is given. Meanwhile, variance decomposition analysis (FEVC) aims to predict the contribution of each variable (the percentage of the variance of each variable) caused by changes in certain variables in a system.

\section{Finding and Discussion}

\section{Finding}

Stunting is a problem of chronic malnutrition in children under five years that is characterised by a very short height and short compared to children his age-the prevalence of stunting in Indonesia in $2010-2018$ at $18.9 \%$. The average distribution of prevalence of stunting in 34 provinces in 2010-2018 shows that the highest prevalence of stunting is in the islands of Nusa Tenggara, Sulawesi, and Kalimantan.

The highest distribution of stunting prevalence in 2010-2018 included East Nusa Tenggara at $24.77 \%$, West Sulawesi at $24.47 \%$, South Sulawesi at $24.25 \%$, West Nusa Tenggara at 23.19\%, and Central Kalimantan at 22.29\%. While the lowest average distribution of stunting prevalence in 2010-2018 included Jakarta at 13.98\%, Riau Islands at 15.67\%, Yogyakarta at $15.75 \%$, and Bali at $15.81 \%$.

The decline in the prevalence of stunting in East Nusa Tenggara tends to be small/stagnant, especially in South Timor Tengah Regency. Due to a large area's geographic conditions with a scattered population, natural conditions that tend to be dry and access to clean water sources are far away, low household welfare, and a shared understanding of nutritious and balanced food (Elmira \& Izzati, 2019).

The prevalence of stunting in West Sulawesi is still very high and categorised as quite serious. Demographic characteristics such as education of mothers and fathers at junior high school, history of maternal antenatal care, history of consumption of blood-supplemented tablets during maternal pregnancy, and maternal age at delivery outside the age range of 2135 have had an impact on the incidence of stunting in children under five in West Sulawesi (Ardian \& Utami, 2020).

Mothers' education and exclusive breastfeeding affected the high prevalence of stunting in children under five in South Sulawesi. Based on (Mustamin, Asbar, \& Budiawan, 2018) study using Nutritional Status Assessment (PSG) 2015 from the South Sulawesi Health Office, it shows that stunting is relatively high, namely $44 \%$ and mothers with less education $(27.7 \%)$ have stunting; stunting was found in children who do not exclusive breastfeeding (0.9\%); maternal education and exclusive breastfeeding are significant factors in the incidence of stunting in South Sulawesi.

Based on Anggraini (2019) study using data from the Indonesian Family Life Survey wave 5 (IFLS-5), the high rate of stunting in West Nusa Tenggara occurs in children aged 12-59 months, including birth weight children's anemia status, maternal age at delivery, and maternal education. The study results explain that first, babies who have a birth weight of fewer than 2500 grams have a 3.03 times greater risk of experiencing stunting. Children with anemia had a 2.199 times greater risk of experiencing stunting. Second, babies born to mothers under 18 years of age have a 6,876 times risk of experiencing stunting. Third, mothers with higher education reduce the risk of stunting in children. Fourth, the dominant risk factor for the incidence of stunting in this study was the mother's age at childbirth, less than 18 years. 
From the results of identification carried out, toddlers are very short and short in Indonesia, and the percentage is still high. Maternal health and nutritional conditions before and during pregnancy after delivery affect fetal growth and the risk of stunting. Other factors affecting the mother are the posture of the mother (short), the distance of the pregnancy is too close, the mother who is still a teenager, and the intake of nutrients that are lacking during pregnancy.

Socioeconomic factors in stunted children also have a significant relationship to the mother's work status, the environment in which she lives can reach health facilities, access to safe water and proper sanitation, government intervention, and the role of cross-sectoral and community settings in stunting handling in Indonesia.

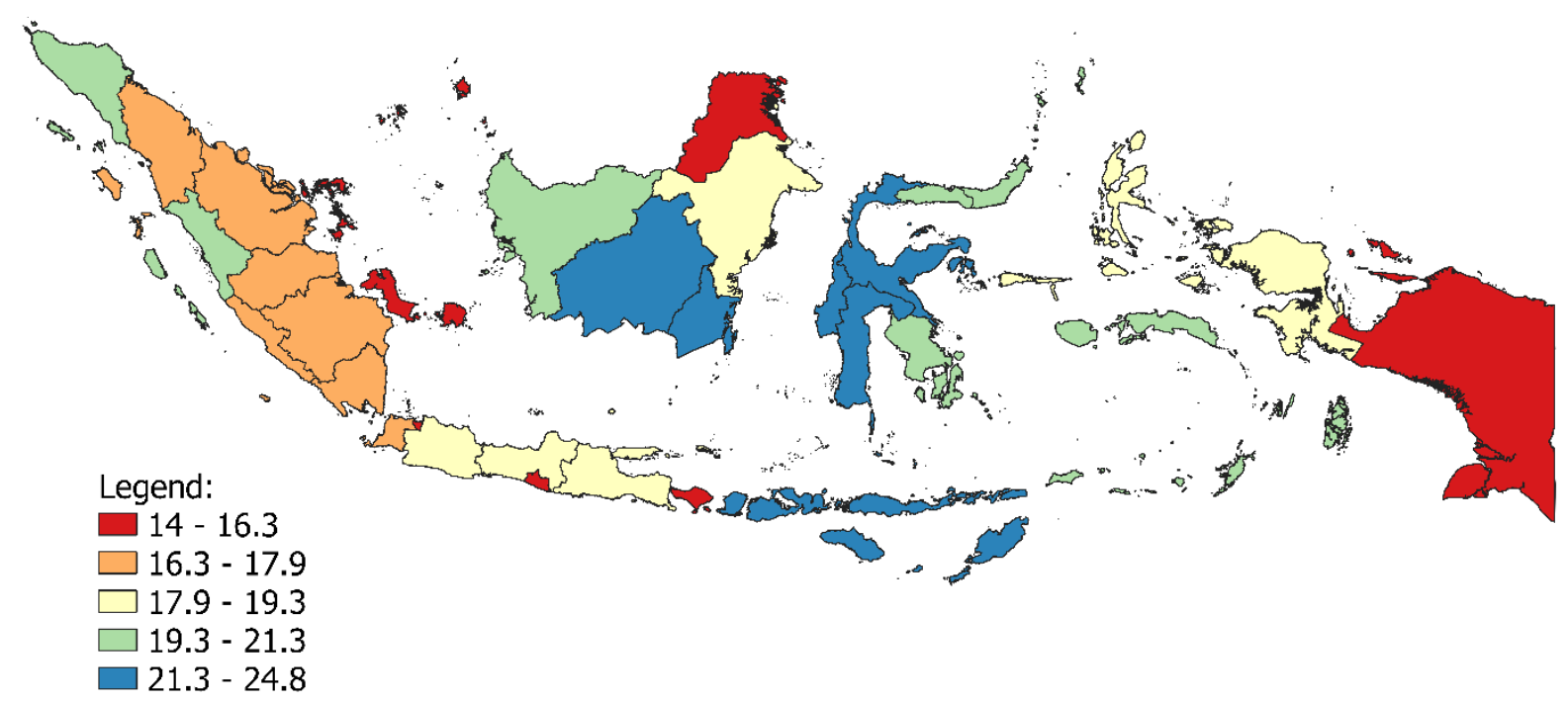

Source: Author's Calculation

Figure 2: The Average Distribution of the Prevalence of Stunting in 34 Provinces in Indonesia, 2010-2018 (\%)

Poverty is a phenomenal problem throughout history. Poverty cannot be defined simply in terms of survival because it is not only related to the ability to meet material needs but is also closely related to other dimensions of human life. Poverty is considered by many experts to be an essential factor causing stunting in children under five years because poor household conditions cannot meet the nutritional intake for their children, so the child becomes stunted. Under these conditions, the growth and development of children can hamper so that in the future, it will produce quality human resources.

Data from Figure 3 shows that the average distribution of poor people in Indonesia in 2010-2018 was 7.83\%. The highest average distribution on poverty in Indonesia in 2010-2018 was West Nusa Tenggara at $19.91 \%$, Bengkulu at $16.95 \%$, South Sumatra $13.49 \%$, Yogyakarta at 12.52, and Central Java 12.08. While the provinces that had the lowest distribution of poverty in 2010-2018 included North Moluccas at 3.31\%, Bangka Belitung Islands at 3.33\%, Jakarta at 3.71\%, South Kalimantan at 3.81, and Bali at 3.81\%.

The high percentage of poverty in an area has an impact on the lack of community access to meet food needs and access to health facilities. The problem of malnutrition in children under five is not new, but this problem remains actual to be discussed, which is reflected by an increase in Protein Energy Malnutrition (PEM) in areas that have a high percentage of poor people. In general, children under five who live in poor households in priority areas for food insecurity have a higher percentage of nutritional disorders than non-priority areas. 


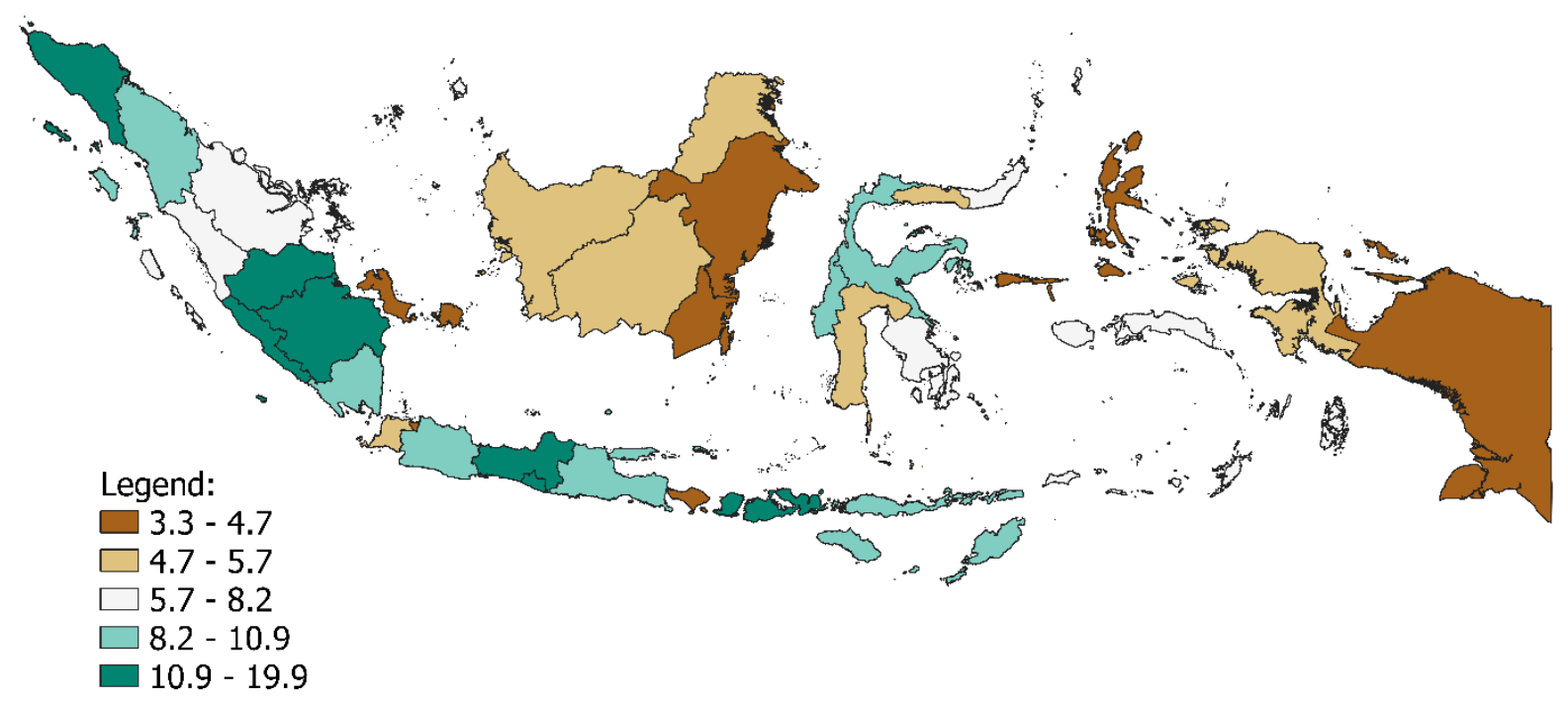

Source: Author's Calculation

Figure 3: The Average Distribution of Poor People in 34 Provinces in Indonesia, 2010-2018 (\%)

Economic growth is the development of the economic activity, which causes the goods and services produced in the community to increase. The data in Figure 4 explain that the average distribution of Indonesia's economic growth in 2010-2018 at 5.68\%. Provinces that had the highest average percentage of economic growth were Central Sulawesi at 9.11\%, Southeast Sulawesi at $7.83 \%$, West Sulawesi at $7.74 \%$, South Sulawesi at 7.63\%, and Gorontalo at $7.07 \%$.

The provinces with the lowest average percentage of economic growth were East Kalimantan at $2.58 \%$, Riau at $2.74 \%$, Aceh at 2.83, West Nusa Tenggara at 3.5\%. However, when viewed from the distribution of GRDP, the contribution of GRDP from provinces in Java and Sumatra is compared to provinces in Kalimantan, Sulawesi, Moluccas, and Papua. High economic growth has an impact on income inequality.

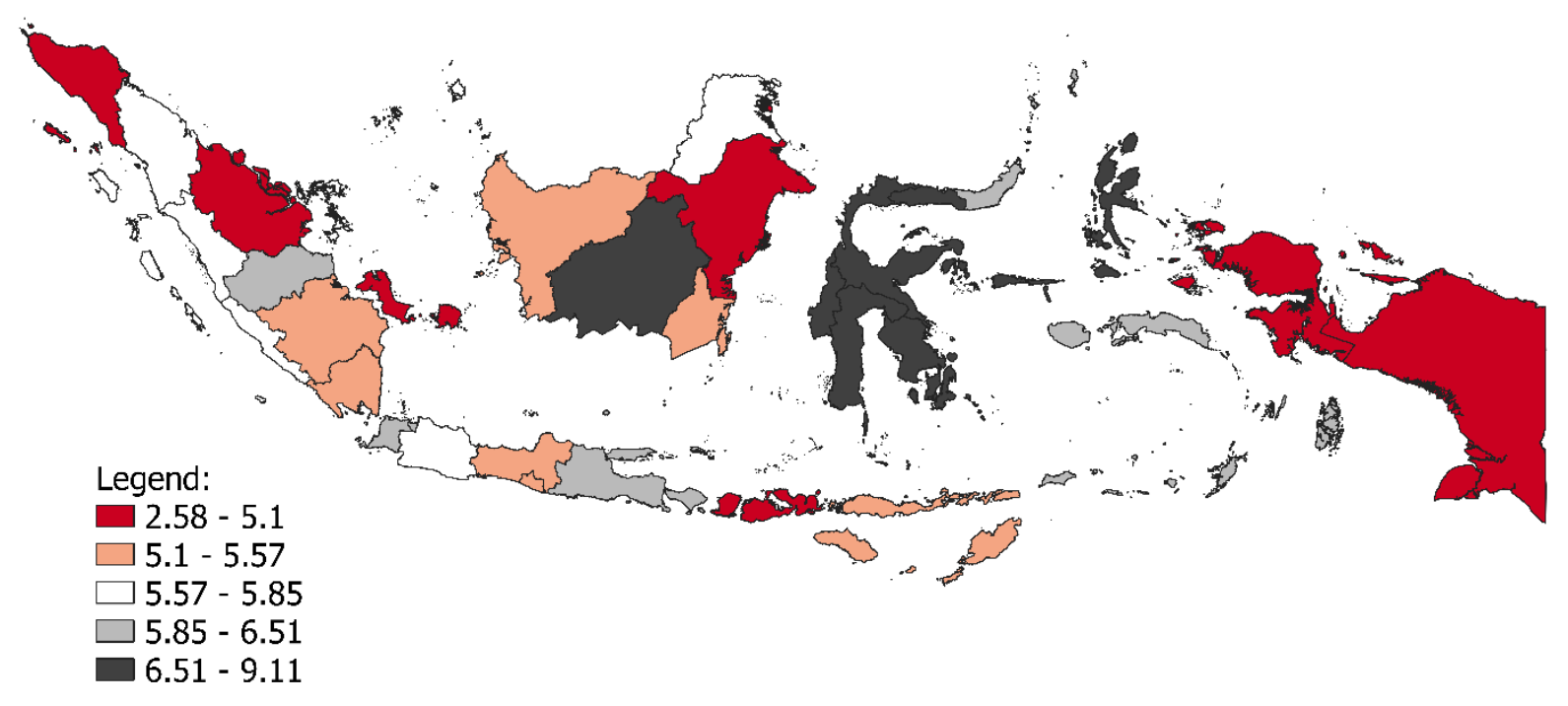

Source: Author's Calculation

Figure 4: The Average Distribution of Economic Growth in 34 Provinces in Indonesia, 20102018 (\%) 
Income inequality is an essential issue for the development of every country. The main problem with the distribution of income is the difference in the distribution of income (Purwono et al., 2021; Solihin et al., 2021). Income inequality is a measure of the distribution of people's income in an area or region in a certain period. The higher the income inequality, the more unequal the income distribution in society.

From the results of the percentage of poor people and the prevalence of stunting classification in 34 provinces in Indonesia using Klassen's typology analysis in Figure 4, poverty has an impact on the high prevalence of stunting in Indonesia. In Quadrant I, six provinces have the highest average percentage of poverty and prevalence of stunting, namely East Nusa Tenggara, West Sulawesi, South Sulawesi, West Nusa Tenggara, Central Kalimantan, and Central Sulawesi.

The high of poor people cause areas with a high incidence of stunting in areas with a high percentage of poverty. Stunting prevention efforts can begin with counseling and demonstration counseling in adolescents to prevent anemia and chronic lack of energy with balanced nutritional intake. Also, efforts to mature the age of marriage must continue to be improved. The incidence of stunting can be resolved during the first 1,000 days of life or from the period of pregnancy of the mother to the child born to two years and when the child's brain develops optimally and has an impact on long-term economic improvement.

Provinces included in Quadrant II, namely South Sulawesi, Central Kalimantan, South Kalimantan, Gorontalo, West Kalimantan, Southeast Kalimantan, West Sumatra, North Sulawesi, and West Papua have poverty below the national average and above the national average for the case of toddlers who are stunted. Therefore, the government must be able to reduce poverty levels with effective poverty reduction programs and investments to improve nutritional status. The benefits will be very useful in improving the health, education, and productivity of human resources.

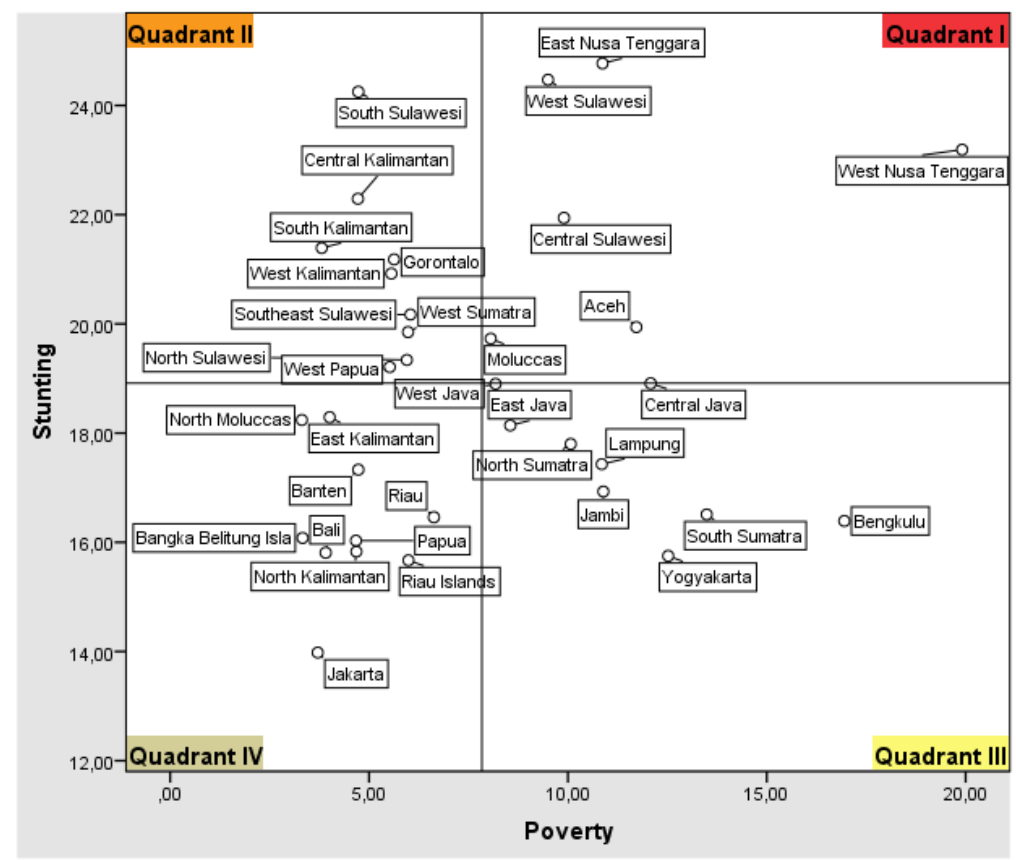

Source: Author's Calculation

Figure 5: Classification of Percentage Poor People and Prevalence of Stunting in 34 Provinces in Indonesia, 2010-2018 (\%) 
In Quadrant III, there are eight provinces, namely East Java, West Java, Central Java, North Sumatra, Lampung, Jambi, South Sumatra, Bengkulu, and Yogyakarta. The percentage of poor people and the prevalence of stunting in the provinces contained in Quadrant III is below the national average. The government must be able to reduce poverty levels with effective poverty reduction programs. Thus, our society does not continue to live in poverty and weakness and can become a great nation. Of course, each program must create an independent, creative and productive society. The government must also supervise and evaluate the system for determining the target recipients of social assistance programs. It also needs to be implemented so that governance can be sustainable. The government must also improve nutrition and achieve the target of stunting reduction by carrying out food fortification or enrichment of micronutrients in food ingredients.

The provinces in Quadrant IV consist of North Moluccas, East Kalimantan, Banten, Riau, Papua, Bali, Bangka Belitung Islands, North Kalimantan, Riau Islands, and Jakarta. The province in Quadrant IV has a high percentage of poor people than the national average but has a lower prevalence of stunting than the national average. Programs and policies in reducing the prevalence of stunting, such as improving access to clean water and proper sanitation and other health, as well as improving community behavior that leads to healthy community movements.

The classification results of Klassen's typology in Figure 6 show the prevalence of stunting and economic growth in Indonesia. In Quadrant I, there are eight provinces, namely West Sulawesi, South Sulawesi, Central Kalimantan, Central Sulawesi, Gorontalo, Moluccas, Southeast Sulawesi, West Sumatra, and North Sulawesi which have a percentage of economic growth and stunting prevalence above the national average. Therefore, an increase in programs and policies for inclusive economic growth is needed to reduce the prevalence of stunting in the provinces in Quadrant I as the main priority in preventing programs to reduce the prevalence of stunting to achieve the target of SDGs 2030, namely to reduce stunting to $40 \%$.

In Quadrant II, there are six provinces, namely East Nusa Tenggara, West Nusa Tenggara, South Sulawesi, West Sulawesi, West Papua, and Aceh which have economic growth below the national average and stunting conditions above the national average. Efforts are made by the government now and in the future to improve the effectiveness and efficiency of programs and policies in reducing the prevalence of stunting, which together will accelerate economic growth.

In Quadrant III, there are eight provinces, namely East Java, North Moluccas, Banten, Jambi, Bengkulu, Bali, Riau Islands, and Jakarta, which have economic growth and the prevalence of stunting below the national average. Therefore, the government must continue to work hard to improve program interventions to reduce stunting and economic growth that is inclusive and sustainable.

In Quadrant IV, there are ten provinces, namely West Java, North Sumatra, East Kalimantan, Lampung, South Sumatra, Riau, Papua, Bangka Belitung Islands, North Kalimantan, Yogyakarta which have economic growth and the prevalence of stunting above the national average. Therefore, increasing programs and policies to encourage the development of leading sectors such as agriculture, plantation, and industry. So that inclusive and sustainable economic growth can be felt by all people. The results of Klassen's typology analysis mean that human resources have an impact on economic potential and high productivity. Thus, if the prevalence of stunting continues to increase in Indonesia, the perceived economic potential is also high nationally. Meanwhile, high economic growth does not have an impact on reducing 
the prevalence of stunting but has an impact on increasing inequality, which simultaneously increases poverty in Indonesia.

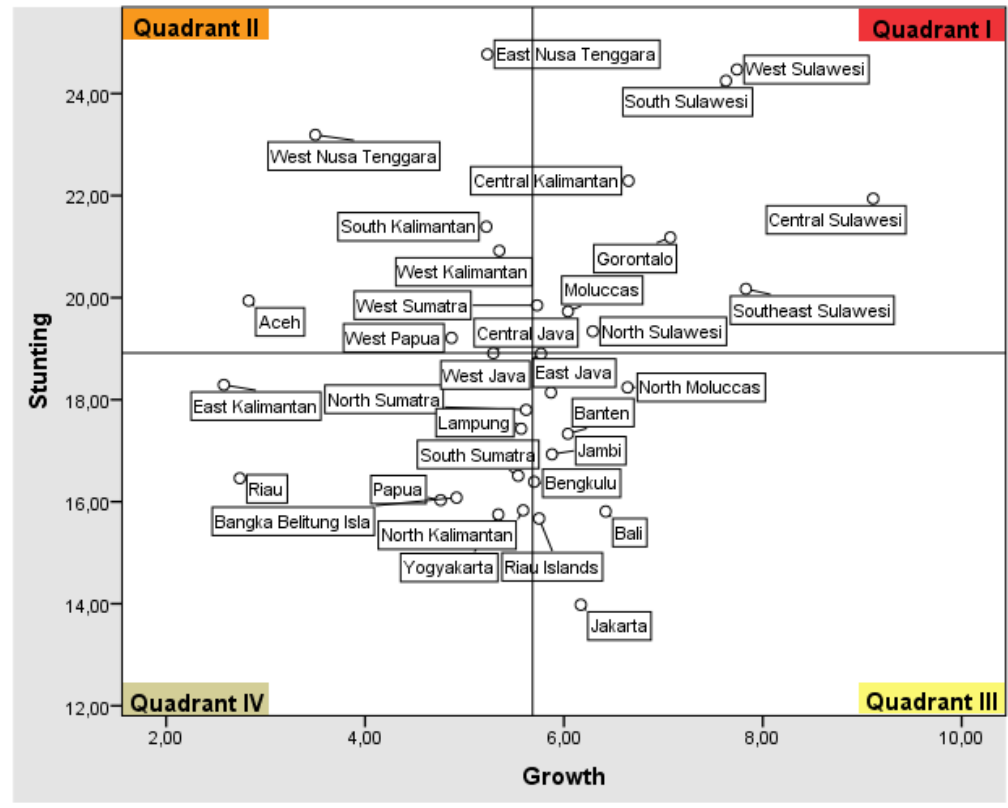

Source: Author's Calculation

Figure 6: Classification Percentage of Economic Growth and Prevalence of Stunting in 34 Provinces in Indonesia, 2010-2018 (\%)

\section{Discussion}

Unit Roots

The first step in estimating the VAR model is the stationary data test with the Hadri test method (Hadri, 2000). Based on the Hadri test, it is known that the variable of the prevalence stunting, poverty, and economic growth is stationary at a level of $1 \%$.

Table 3: Unit Roots

\begin{tabular}{cccc}
\hline Variables & Hadri Z-stat & Prob. & Summary \\
\hline$\Delta$ Stunting & 6.20741 & $0.0000^{*}$ & Stationary \\
\cline { 2 - 3 } & 6.31282 & & \\
\hline \multirow{2}{*}{$\Delta$ Poverty } & 6.69770 & $0.0000^{*}$ & Stationary \\
\cline { 2 - 3 } & 7.67910 & & Stationary \\
\hline & 4.41874 & $0.0000^{*}$ & \\
\hline
\end{tabular}

Note: all variables are stationary at level $1 \%$

Source: Author's Calculation

\section{Optimum Lag}

Optimum lag testing is beneficial to eliminate the autocorrelation problem in the VAR model. To find an optimum lag for this model, I employ five criteria, i.e., LR, FPE, AIC, SC, and HQ. I get the optimum lag-2.

Table 4: Optimum Lag 


\begin{tabular}{ccccccc}
\hline Lag & LogL & LR & FPE & AIC & SC & HQ \\
\hline 0 & -710.6842 & NA & 366.5860 & 14.41786 & 14.49650 & 14.44968 \\
\hline 1 & -443.2562 & 513.2457 & 1.980988 & 9.197095 & $9.511655^{*}$ & 9.324366 \\
\hline 2 & -424.1364 & 35.5377 & $1.615642^{*}$ & $8.992654^{*}$ & 9.543134 & $9.215379^{*}$ \\
\hline
\end{tabular}

Source: Author's Calculation

\section{Cointegration Test}

Cointegration testing in this study was carried out using the Kao Residual Cointegration Test. This test serves to determine whether the dependent and independent variables have a long-term relationship or not. This study uses the Kao test based on the Engle \& Granger (1987) two-step residual-based Kao Residual Cointegration Test. Based on the results of the Kao Residual Cointegration Test, it is known that the $p$-value $<0.05$.

Table 5: Cointegration Test

\begin{tabular}{|c|c|c|}
\hline ADF & t-statistic & Prob. \\
\hline & 2.392376 & $0.0084 *$ \\
\hline Residual variance & & \\
\hline HAC variance & & \\
\hline
\end{tabular}

\section{Vector Error Correction Model (VECM)}

The VECM estimation results in Table 4 show that in the short term, there is no causality between the prevalence of stunting, poverty, and economic growth in Indonesia. In the short term, the causality of these three variables cannot be predicted due to the complexity of the problem, the high prevalence of stunting, and poverty who need more attention. Economic growth must be able to become real data to bring us closer to the problem of poverty reduction and stunting prevention, not to reduce the problem through numbers that do not touch the substance of the underlying problem. The reduction of poverty and stunting cases in Indonesia cannot be resolved in the short term, for this problem, an inclusive and sustainable economic development policy is needed.

The prevalence of the stunting model equation shows an ECT result of 0.02 and is significant at the $10 \%$ level. It means that there is a causality between poverty and economic growth in the long-term on the prevalence of stunting in Indonesia. The results of this study indicate that poverty and economic growth have a direct effect on accelerating the reduction of stunting cases (Mary, 2018; McGovern et al., 2017; and de Onis \& Branca, 2016).

Stunting is an invisible form of the problem of hunger, which is generally invisible, and poverty is considered to be an essential factor causing stunting in children under five years. The complexity of the problem is the high prevalence of stunting and the percentage of poor people needing more attention. A comprehensive improvement needs to be made. Economic growth should be able to be real data to get us closer to the problem of stunting prevalence and poverty, not to reduce the problem through numbers that do not touch the substance of the underlying problem.

Poverty shows a significant result on ECT of 0.06 at the $1 \%$ significance level. It means that there is a causal relationship between economic growth and the prevalence of stunting 
in the long-term. Any shock that occurs in the system will cause economic growth, and the prevalence of stunting in the short term can adjust to restore equilibrium in the long term by $0.06 \%$. Literature studies suggest that economic growth can reduce poverty levels if welfare can be shared equally.

Economic growth can also increase poverty and inequality by increasing the concentration of wealth on a few people. It can also increase malnutrition among toddlers born to poor and vulnerable families due to their inability to spend safe, healthy, and nutritious food (Niyimbanira, 2017; Hassan et al., 2015; and Ncube et al., 2014).

Indonesia's 15 years of continued economic growth have helped reduce poverty and create a thriving middle class. Growth over the past decade has benefited only the wealthiest $20 \%$ of the population, while the remaining $80 \%$ of the population-205 million peoplelagged. Increasing disparities in living standards and the increasing concentration of wealth in the hands of a few people have resulted in a relatively high level of inequality in Indonesia and rising more rapidly than some countries in East Asia.

Despite Indonesia's rapid economic growth in the past 20 years, there are still many malnourished children and high poverty rates in various regions. This fact shows that the acceleration of economic growth and improvement in physical sector development are out of sync with the improvement of nutrition and public welfare. Economic growth by itself cannot be considered an end goal.

Fioramonti (2013) sees that economic growth that relies on calculating GDP figures has created vast inequalities in various aspects of society. For this reason, economic development must pay attention to improving the quality of life lived and the freedom enjoyed by the people of a nation. Todaro \& Smith (2012) argues that the welfare of the lower middle class can be presented from the socioeconomic status of the community. Socioeconomic status is characterised by poverty alleviation and access to better health facilities. The increasing number of stunting cases shows that economic growth does not at all represent the public welfare index.

Table 6: Vector Error Correction Estimates

\begin{tabular}{|c|c|c|c|}
\hline \multicolumn{4}{|c|}{ Short-run coefficient } \\
\hline \multirow[t]{2}{*}{ ECT: } & \multicolumn{3}{|c|}{ Dependent Variable } \\
\hline & $\Delta$ (Stunting) & $\Delta$ (Poverty) & $\Delta$ (Growth) \\
\hline \multirow[t]{2}{*}{$\Delta$ Stunting } & - & 0.014899 & 0.116325 \\
\hline & & [0.00484] & [0.01499] \\
\hline \multirow[t]{2}{*}{$\Delta$ Poverty } & 0.011694 & - & 0.048102 \\
\hline & [0.00692] & & {$[0.00620]$} \\
\hline \multirow[t]{2}{*}{$\Delta$ Growth } & 0.140475 & 0.074009 & - \\
\hline & {$[0.08317]$} & {$[0.02404]$} & \\
\hline \multicolumn{4}{|c|}{ Long-term coefficient } \\
\hline \multirow[t]{2}{*}{ ECT: } & $0.028280^{*}$ & $0.060161 * *$ & $0.577814^{* *}$ \\
\hline & {$[0.016743]$} & [0.002001] & [0.074456] \\
\hline $\mathrm{N}$ & 306 & 306 & 306 \\
\hline
\end{tabular}

Note robust standard error in parentheses. ${ }^{*} p<0.1,{ }^{* *} p<0.01$ Source: Author's Calculation 
The estimation result of economic growth shows an ECT of 0.57 with a significance level of $1 \%$. It means that there is a causal relationship between poverty and the prevalence of stunting on long-term economic growth. When there is a shock to the system, poverty and the prevalence of stunting can adjust to restore in a long-term equilibrium position of $0.57 \%$.

The results of this study are in line with (Mary, 2018; McGovern et al., 2017; Biadgilign et al., 2016; Vollmer et al., 2014; and Harttgen et al., 2013) that poverty and the prevalence of stunting have a direct effect on economic growth. It proves the fact that the country's economic growth is accompanied by socioeconomic development and the improvement of the livelihoods and welfare of the poor. Specific interventions for specific nutrition and sensitive nutrition can also be recommended to have an impact on the massive reduction of malnutrition in Indonesia.

\section{Impulse Response Function}

Impulse Response Function (IRF) analysis shows the dynamic response of one variable to the shock of another variable. IRF analysis not only shows short-term respect but can analyse for several horizons ahead for long-term information. In this analysis, we can see the response of each variable if there is an absolute shock equal to the standard error in each equation. The horizontal axis represents the period in years, and the vertical axis shows the response value as a percentage.

The IRF analysis was conducted to look at the response of the prevalence of stunting to poverty and economic growth. The response of poverty to economic growth and the prevalence of stunting. And the response of economic growth to the prevalence of stunting and poverty. The period used in analysing the responses of each variable is the next ten years in 34 provinces in Indonesia.

The results of the IRF analysis in Figure 7 explain that the prevalence of stunting harms poverty in the period 3 to 10 if there is a shock to poverty, the prevalence of stunting will be negatively responded. The response of the prevalence of stunting to economic growth has a negative impact in the period 1 to 10 , if there is a shock to economic growth, it is responded positively by one of the prevalences of stunting.

Response to Cholesky One S.D. (d.f. adjusted) Innovations

Response of STUNTING to POVERTY

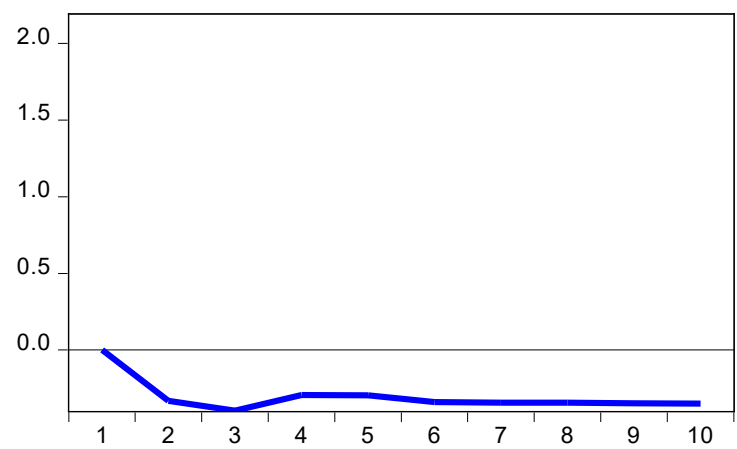

Response of STUNTING to GROWTH

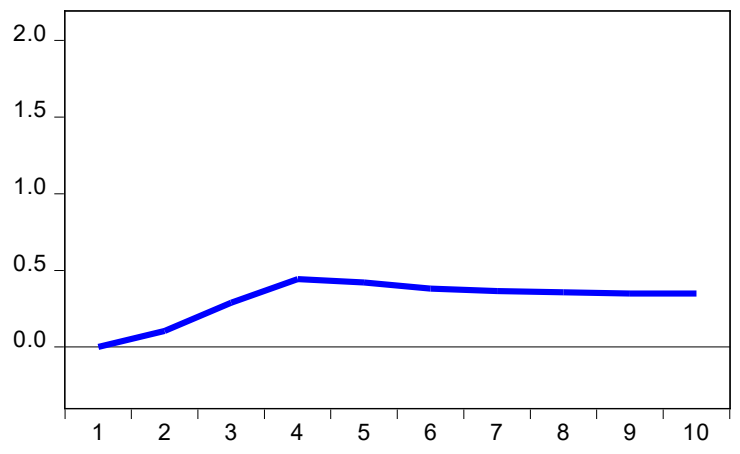

Source: Author's Calculation

Figure 7: Impulse Response Function The Prevalence of Stunting Due to Shock Poverty and Economic Growth 
The results of the IRF analysis in Figure 8 show that poverty harms the prevalence of stunting in the period 1 to 10 if there is a shock to poverty it is responded positively by one of the prevalence of stunting. The response from poverty harms economic growth in the period 1 to 10 , if there is a shock to economic growth, poverty will respond negatively.

Response to Cholesky One S.D. (d.f. adjusted) Innovations

Response of POVERTY to STUNTING

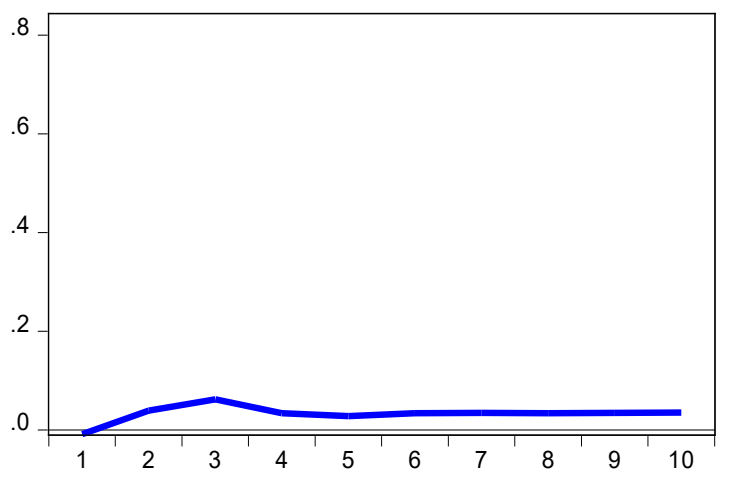

Response of POVERTY to GROWTH

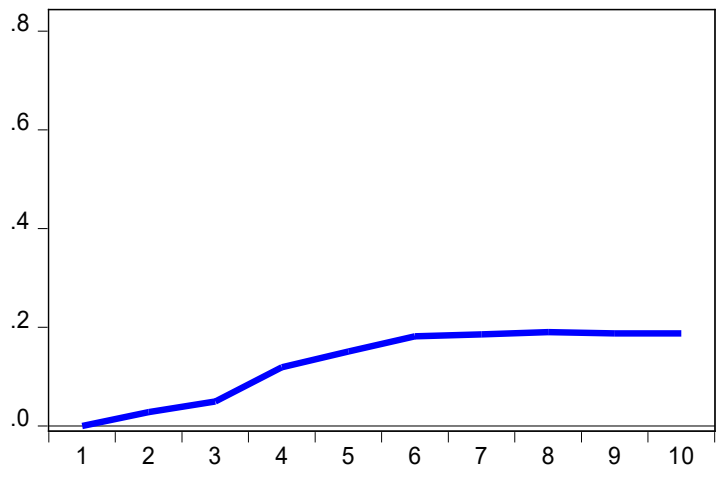

Source: Author's Calculation

Figure 8: Impulse Response Function Poverty Due to Shock Prevalence of Stunting and Economic Growth

The results of the IRF analysis in Figure 9 explain that economic growth has a positive impact on the prevalence of stunting in the period 1 to 10 on affirmative action if there is a shock to economic growth it is responded positively by one of the prevalence of stunting. The response of economic growth harms poverty in periods 1 to 9; if there is a shock to poverty, economic growth will respond negatively.

Response to Cholesky One S.D. (d.f. adjusted) Innovations

Response of GROWTH to STUNTING

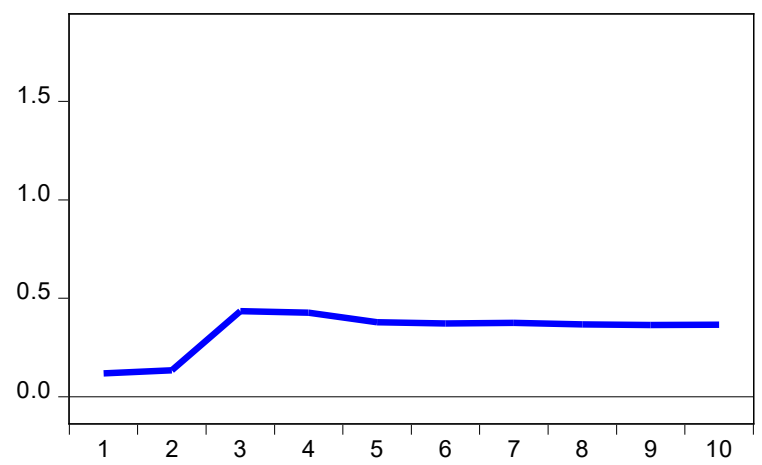

Response of GROWTH to POVERTY

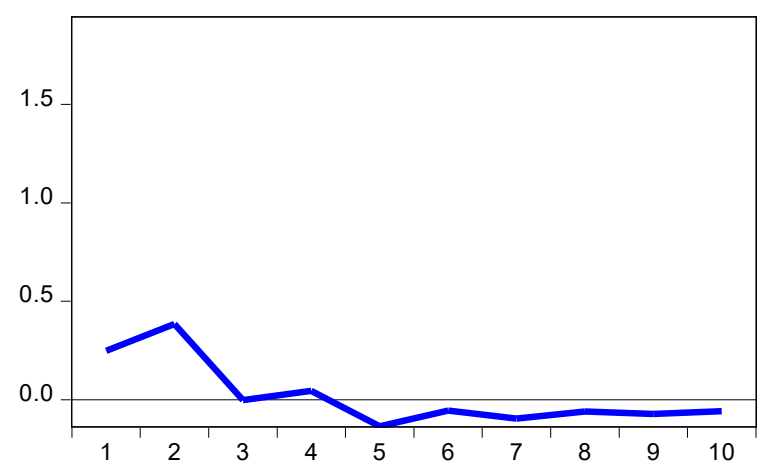

Source: Author's Calculation

Figure 9: Impulse Response Function Economic Growth Due to Shock Prevalence of Stunting and Poverty

Forecast Error Variance Decomposition (FEVD)

In addition to impulse response, the VAR model provides an analysis of Variance Decomposition (VD) or also called Forecast Error Variance Decomposition (FEVD). Variance decomposition provides a different method for describing dynamic VAR systems compared to 
the previous impulse response analysis.

This variance decomposition analysis illustrates the relative importance of each variable in the VAR system due to the shock. It is useful for predicting the contribution of the percentage of variance to each variable due to changes in certain variables in the VAR system.

The prevalence of stunting in the $2^{\text {nd }}$ period has a variance decomposition of $98.4 \%$, the rest of it from poverty was $1.4 \%$ and economic growth of $0.14 \%$, while in the $10^{\text {th }}$ period by $90.4 \%$, the rest of it poverty was $4.5 \%$ and economic growth was $4.95 \%$.

Poverty in the $2^{\text {nd }}$ period had a $99.7 \%$ variance decomposition, the rest of the prevalence of stunting was $0.19 \%$, and economic growth was $0.09 \%$, while in the $10^{\text {th }}$ period, it was $96.4 \%$, the rest of the prevalence of stunting was $0.20 \%$, and economic growth was $3.30 \%$.

Economic growth in the $2^{\text {nd }}$ period had a variance decomposition of $94.9 \%$, the rest of poverty was $4.39 \%$, and the prevalence of stunting was $0.67 \%$, while in the $10^{\text {th }}$ period it was $77.2 \%$, the rest of the prevalence of stunting was $18.8 \%$, and poverty was $3.91 \%$.

Table 7: Forecast Error Variance Decomposition

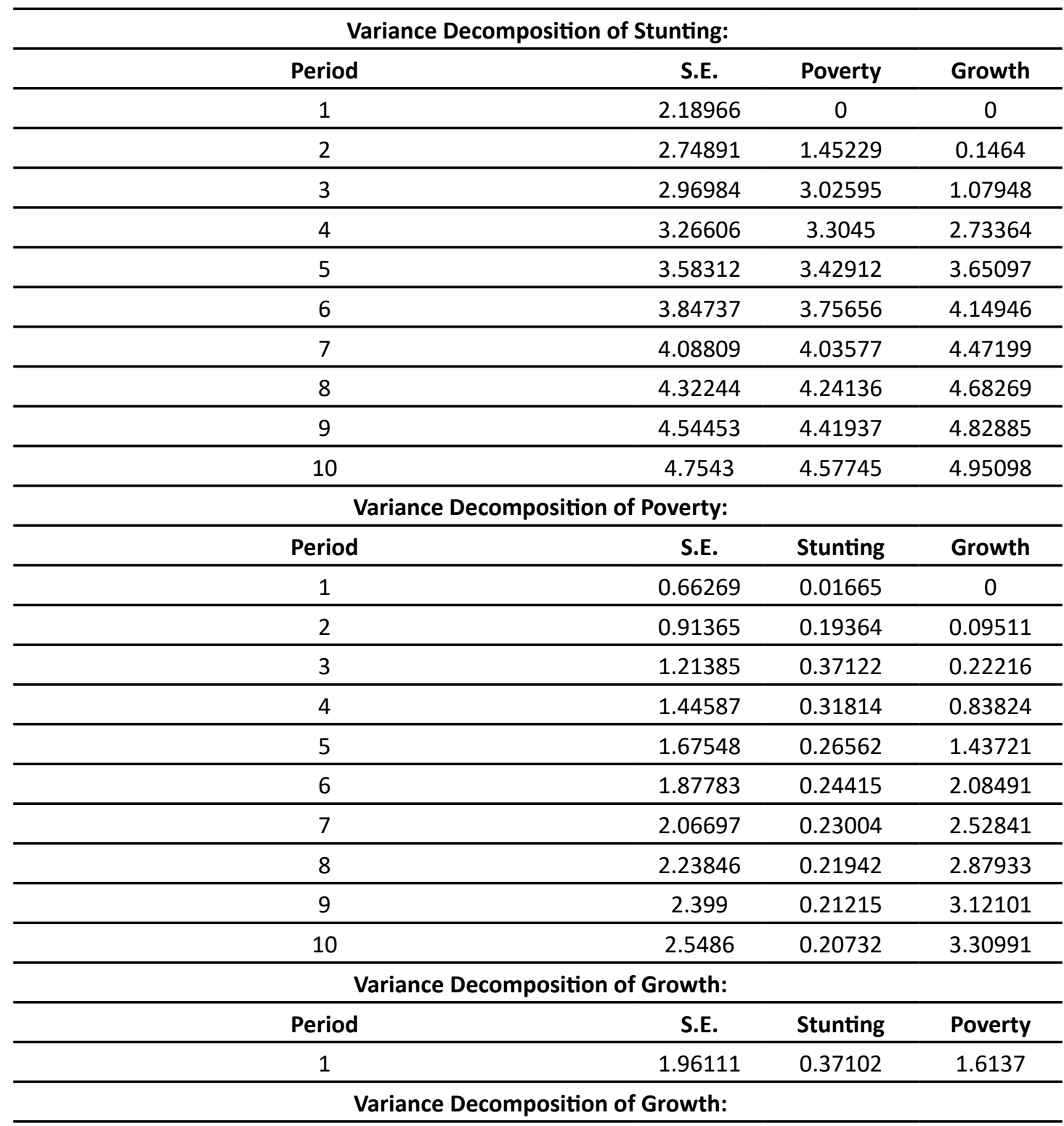




\begin{tabular}{|c|c|c|c|}
\hline Period & S.E. & Stunting & Poverty \\
\hline 2 & 2.1903 & 0.67824 & 4.39051 \\
\hline 3 & 2.32426 & 4.09635 & 3.89902 \\
\hline 4 & 2.36789 & 7.20169 & 3.79336 \\
\hline 5 & 2.40318 & 9.46383 & 3.99156 \\
\hline 6 & 2.43256 & 11.5712 & 3.94732 \\
\hline 7 & 2.46431 & 13.589 & 3.99754 \\
\hline 8 & 2.49352 & 15.4377 & 3.95998 \\
\hline 9 & 2.52324 & 17.1618 & 3.94959 \\
\hline 10 & 2.55253 & 18.829 & 3.91188 \\
\hline
\end{tabular}

Cholesky Ordering: Stunting Poverty Growth

Source: Author's Calculation

\section{Conclusion}

The results of this study indicate that the prevalence of stunting has evidence of directional causality from poverty and long-term economic growth of $0.02 \%$ in the long-term. Stunting reduction needs to be focused on in all provinces in Indonesia. Stunting can not be done alone because it will not have a significant impact. Efforts to prevent stunting must be carried out in an integrated and convergent manner with a multi-sector approach.

To that end, the government must ensure that all ministries/institutions, as well as development partners, academics, professional organisations, civil society organisations, private companies, and the media, can work together hand in hand in accelerating the prevention of stunting in Indonesia. Not only at the central level, integration and convergence of stunting prevention efforts must also occur at the local level up to the village level.

Poverty shows a causal relationship to economic growth and the prevalence of stunting of $0.06 \%$ in the long term. Poverty reduction through efforts to reduce community spending, and encourage increased income, among others, through the improvement and expansion of social assistance and social security.

This study found directional causality of economic growth to the prevalence of stunting and poverty by $0.57 \%$ in the long term. The economic growth accompanied by socioeconomic development and increased welfare can reduce poverty and investment in access to food and health facilities can have an impact on reducing the prevalence of stunting in Indonesia.

Limitations in this study use provincial level aggregate data from 2010-2018. Even though the data coverage has represented all provinces in Indonesia, the availability of data in a short period causes the analysis to be carried out limited. It is recommended that future studies use microeconomic data such as the Indonesia Basic Health Research and the Indonesian Family Life Survey (IFLS).

\section{Acknowledgment}

I would like to thank the anonymous reviewers and editors at the Journal of Developing Economies for their careful reading of my manuscript and their many insightful comments and suggestions. The usual disclaimer applies, and views are my sole responsibility. 


\section{References}

Adair, L. S., Fall, C. H. D., Osmond, C., Stein, A. D., Martorell, R., Ramirez-Zea, M., ... Victora, C. G. (2013). Associations of linear growth and relative weight gain during early life with adult health and human capital in countries of low and middle income: Findings from five birth cohort studies. The Lancet, 382(9891), 525-534. https://doi.org/10.1016/S01406736(13)60103-8

Alfarisi, R., Nurmalasari, Y., Nabilla, S. (2019). Status Gizi Ibu Hamil Dapat Menyebabkan Kejadian Stunting Pada Balita [Nutritional Status of Pregnant Women Can Cause Stunting In Toddlers]. JKM (Jurnal Kebidanan Malahayati), 5(3), 271-278.

Anggraini, N. D. (2019). Analisis Faktor Resiko Kejadian Stunting Pada Anak Usia 12-59 Bulan Di Provinsi Nusa Tenggara Barat [Risk Factor Analysis of Stunting Incidence in Children aged 12-59 Months in West Nusa Tenggara Province]. Medical Technology and Public Health Journal, 3(1), 86-93. https://doi.org/10.33086/mtphj.v3i1.649

Anugraheni, H. S., \& Kartsurya, M. I. (2012). Faktor Risiko Kejadian Stunting Pada Anak Usia 12-36 Bulan di Kecamatan Pati, Kabupaten Pati [Risk Factors for Stunting in Children aged 12-36 Months in Pati District, Pati Regency]. Journal of Nutrition College, 1(1), 30-37. https://doi.org/https://doi.org/10.14710/jnc.v1i1.725

Ardian, D., \& Utami, E. D. (2020). Pengaruh Karakteristik Demografi Terhadap Kejadian Stunting Pada Balita di Provinsi Sulawesi Barat [The Effect of Demographic Characteristics on Stunting Incidence in Toddlers in West Sulawesi Province]. Seminar Nasional Official Statistik 2020: Statistics in the New Normal: A Challenge of Big Data and Official Statistics, 397-406.

Barker, D. J. P. (2007). Introduction: The window of opportunity. Journal of Nutrition, 137(4), 1058-1059. https://doi.org/10.1093/jn/137.4.1058

Bata, P., Binh, L., Vonaesch, P., Tondeur, L., Nguyen, L., Frank, T., ... Vray, M. (2017). Factors associated with stunting in healthy children aged 5 years and less living in Bangui (RCA).

Biadgilign, S., Shumetie, A., \& Yesigat, H. (2016). Does economic growth reduce childhood undernutrition in Ethiopia? PLOS ONE, 11(8), 1-14. https://doi.org/10.1371/journal. pone. 0160050

Casale, D., Espi, G., \& Norris, S. A. (2018). Estimating the pathways through which maternal education affects stunting : evidence from an urban cohort in South Africa Public Health Nutrition. (17), 13-16. https://doi.org/10.1017/S1368980018000125

Crahay, P., Gomez, A., Mattinen, H., Grosjean, L., Aissa, M. A., Brown, R., \& Swan, S. H. (2010). The threats of climate change on undernutrition: A neglected issue that requires further analysis and urgent actions. SCN News, (38), 1-9. Retrieved from http://www.unscn.org/ files/Publications/SCN_News/SCN_NEWS_38_03_06_10.pdf\%5CnIntroduction

Dao, M.Q. (2008). Human capital, poverty, and income distribution in developing countries.Journal of Economic Studies, 35(4), 294-303. https://doi.org/10.1108/01443580810895590

de Onis, M., \& Branca, F. (2016). Childhood Stunting: A global perspective. In Maternal and Child Nutrition (Vol. 12). https://doi.org/10.1111/mcn.12231

Elmira, E. S., \& Izzati, R. Al. (2019). Strategi menurunkan angka stunting di Indonesia: me- 
metakan status gizi balita hingga tingkat desa [Strategy to reduce stunting in Indonesia: mapping the nutritional status of children under five to the village level]. Retrieved March 31, 2021, from The Conversation website: https://theconversation.com/strategi-menurunkan-angka-stunting-di-indonesia-memetakan-status-gizi-balita-hingga-tingkat-desa-121049

Engle, R. F., \& Granger, C. W. J. (1987). Co-Integration and Error Correction : Representation , Estimation , and Testing. Econometrica, 55(2), 251-276.

Fioramonti, L. (2013). Gross Domestic Problem: The Politics Behind the World's Most Powerful Number. London: Zed Books Ltd.

Frimpong, J., Okoye, D., \& Pongou, R. (2016). Economic Growth, Health Care Reform, and Child Nutrition in Ghana. Journal of African Development, 18(2), 41-60.

Grantham-McGregor, S., Cheung, Y. B., Cueto, S., Glewwe, P., Richter, L., \& Strupp, B. (2007). Developmental potential in the first 5 years for children in developing countries. Lancet, 369(9555), 60-70. https://doi.org/10.1016/S0140-6736(07)60032-4

Habibullah, P. M., Nasim-Us, S. M., \& Ulrika, E. (2016). Socioeconomic inequalities of child malnutrition in Bangladesh. International Journal of Social Economics, 43(12), 1439-1459. https://doi.org/10.1108/IJSE-03-2015-0065

Hadri, K. (2000). Testing for stationarity in heterogeneous panel data. Econometrics Journal, 3, 148-161.

Harttgen, K., Klasen, S., \& Vollmer, S. (2013). Economic Growth and Child Undernutrition in sub-Saharan Africa. Population and Development Review, 39(3), 397-412.

Hassan, S. A., Zaman, K., \& Gul, S. (2015). The Relationship between Growth-Inequality-Poverty Triangle and Environmental Degradation: Unveiling the Reality. Arab Economic and Business Journal, 10(1), 57-71. https://doi.org/10.1016/j.aebj.2014.05.007

Hatta, M., \& Astuti, T. (2018). The Economic Growth Pattern Analysis of Ajatappareng Region Using Klassen Typology Approach. International Journal of Economics, Commerce and Management, VI(9), 672-686.

Hoddinott, J., Alderman, H., Behrman, J. R., Haddad, L., \& Horton, S. (2013). The economic rationale for investing in stunting reduction. Maternal and Child Nutrition, 9(S2), 69-82. https://doi.org/10.1111/mcn.12080

Horrell, S., Humphries, J., \& Voth, H. J. (2001). Destined for deprivation: Human capital formation and intergenerational poverty in nineteenth-century England. Explorations in Economic History, 38(3), 339-365. https://doi.org/10.1006/exeh.2000.0765

Jr., R. H. A. (2004). Economic growth, inequality and poverty: Estimating the growth elasticity of poverty. World Development, 32(12), 1989-2014. https://doi.org/10.1016/j.worlddev.2004.08.006

Khan M M H, \& Kraemer A. (2009). Factors associated with being underweight, overweight and obese among ever-married non-pregnant urban women in Bangladesh. Singapore Medical Journal, 50(8), 804-813.

Kuada, J. (2014). Economic growth and poverty alleviation in Africa - linking hard and soft economics. African Journal of Economic and Management Studies, 5(1), 2-8. https://doi. 
org/10.1108/AJEMS-03-2014-0016

Kustanto, A. (2020). Pertumbuhan Ekonomi Regional di Indonesia: Peran Infrastruktur, Modal Manusia, dan Keterbukaan Perdagangan [Regional Economic Growth in Indonesia: The Role of Infrastructure, Human Capital, and Trade Openness]. Buletin Studi Ekonomi, 25(1), 80-98. https://doi.org/10.24843/BSE.2020.v25.i01.p05

Larrea, C., \& Kawachi, I. (2005). Does economic inequality affect child malnutrition? The case of Ecuador. Social Science and Medicine, 60(1), 165-178. https://doi.org/10.1016/j. socscimed.2004.04.024

Lütkepohl, H. (2006). New Introduction to Multiple Time Series Analysis. Berlin: Springer-Verlag.

Lütkepohl, H. (2011). Vector autoregressive models. In EUI Working Paper ECO 2011/30. https://doi.org/10.4337/9780857931023.00012

Lyakurwa, W. (2009). Prospects for economic governance: resilient pro-poor growth. Foresight, 11(4), 66-81. https://doi.org/10.1108/14636680910982449

Madan, E. M., Haas, J. D., Menon, P., \& Gillespie, S. (2018). Seasonal variation in the proximal determinants of undernutrition during the first 1000 days of life in rural South Asia: A comprehensive review. Global Food Security, 19(August), 11-23. https://doi. org/10.1016/j.gfs.2018.08.008

Martorell, R., Horta, B. L., Adair, L. S., Stein, A. D., Richter, L., Fall, C. H. D., ... Group, C. on H. O. R. in T. S. (2009). Weight Gain in the First Two Years of Life Is an Important Predictor of Schooling Outcomes in Pooled Analyses from Five Birth Cohorts from Low- and Middle-Income Countries. The Journal of Nutrition: Community and International Nutrition, 348-354. https://doi.org/10.3945/jn.109.112300

Mary, S. (2018). How much does economic growth contribute to child stunting reductions? Economies, 6(4). https://doi.org/10.3390/economies6040055

Mayneris, J., \& Jonathan, P. (2018). Metabolic phenotyping of malnutrition during the first 1000 days of life. European Journal of Nutrition. https://doi.org/10.1007/s00394-018$1679-0$

McGovern, M. E., Krishna, A., Aguayo, V. M., \& Subramanian, S. V. (2017). A review of the evidence linking child stunting to economic outcomes. International Journal of Epidemiology, 46(4), 1171-1191. https://doi.org/10.1093/ije/dyx017

Mustamin, Asbar, R., \& Budiawan. (2018). Tingkat Pendidikan Ibu Dan Pemberian Asi Eksklusif Dengan Kejadian Stunting Pada Balita di Provinsi Sulawesi Selatan: Analisis Data Sekunder Laporan Pemantauan Status Gizi Provinsi Sulawesi Selatan Tahun 2015 [Mother's Education Level and Exclusive Breastfeeding with Stunting Incidence in Toddlers in South Sulawesi Province: Secondary Data Analysis Monitoring Report on Nutritional Status of South Sulawesi Province in 2015]. Media Gizi Pangan, 25(1), 25-32.

Ncube, M., Anyanwu, J. C., \& Hausken, K. (2014). Inequality, Economic Growth and Poverty in the Middle East and North Africa (MENA). African Development Review, 26(3), 435-453. https://doi.org/10.1111/1467-8268.12103

Niyimbanira, F. (2017). Analysis of the Impact of Economic Growth on Income Inequality and 
Poverty in South Africa: The Case of Mpumalanga Province. International Journal of Economics and Financial Issues, 7(4), 254-261.

O'Connell, S. A., \& Smith, C. (2016). Economic growth and child undernutrition. The Lancet Global Health, 4(12), e901-e902. https://doi.org/10.1016/S2214-109X(16)30250-9

Ogundari, K., \& Aromolaran, A. (2017). Nutrition and economic growth in sub-Saharan Africa: a causality test using panel data. International Journal of Development Issues, 16(2), 174-189. https://doi.org/10.1108/IJDI-12-2016-0076

Olalekan, A. S. A., Omowonuola, A.-O. A., \& Kehinde, T. H. (2017). Poverty and malnutrition in Africa: a conceptual analysis. Nutrition \& Food Science, 47(6), 754-764. https://doi. org/10.1108/NFS-02-2017-0027

Purwono, R., Wardana, W. W., Haryanto, T., \& Mubin, M. K. (2021). Poverty dynamics in Indonesia: Empirical evidence from three main approaches. World Development Perspectives, 23, 100346.

Rashad, A. S., \& Sharaf, M. F. (2018). Economic Growth and Child Malnutrition in Egypt: New Evidence from National Demographic and Health Survey. Social Indicators Research, 135(2), 769-795. https://doi.org/10.1007/s11205-016-1515-y

Ruel, M. T., \& Alderman, H. (2013). Nutrition-sensitive interventions and programmes: How can they help to accelerate progress in improving maternal and child nutrition? The Lancet, 382(9891), 536-551. https://doi.org/10.1016/S0140-6736(13)60843-0

Smith, L. C., \& Haddad, L. (2015). Reducing Child Undernutrition: Past Drivers and Priorities for the Post-MDG Era. World Development, 68(1), 180-204. https://doi.org/10.1016/j. worlddev.2014.11.014

Solihin, A., Wardana, W. W., Fiddin, E., \& Sukartini, N. M. (2021). Do government policies drive economic growth convergence? Evidence from East Java, Indonesia. Cogent Economics \& Finance, 9(1), 1992875.

Stewart, C. P., Iannotti, L., Dewey, K. G., Michaelsen, K. F., \& Onyango, A. W. (2013). Contextualising complementary feeding in a broader framework for stunting prevention. Maternal \& Child Nutrition, 9(2), 27-45. https://doi.org/10.1111/mcn.12088

Sukmawati, Hendrayati, Chaerunnimah, \& Nurhumaira. (2018). Status Gizi Ibu Saat Hamil, Berat Badan Lahir Bayi dengan Stunting Pada Balita [Mother's Nutritional Status During Pregnancy, Birth Weight of Babies with Stunting in Toddlers]. Media Gizi Pangan, 25(1), 18-25.

Titaley, C. R., Ariawan, I., Hapsari, D., Muasyaroh, A., \& Dibley, M. J. (2019). Determinants of the stunting of children under two years old in Indonesia: A multilevel analysis of the 2013 Indonesia basic health survey. Nutrients, 11(5). https://doi.org/10.3390/nu11051106

TNP2K. (2018). Strategi Nasional Percepatan Pencegahan Anak Kerdil (Stunting) [National Strategy for the Acceleration of Stunting Prevention]. National Team for the Acceleration of Poverty Reduction. Jakarta.

Todaro, M. P., \& Smith, S. C. (2012). Economic Development. Boston: Pearson Education.

UNICEF. (2009). Tracking Progress on Child and Maternal Nutrition: A survival and development priority. United Nations International Children's Fund. New York. 
UNICEF. (2018). Levels and Trends in Child Malnutrition. United Nations International Children's Fund. New York.

Uwiringiyima, V., Ocke, M. C., Amer, S., \& Veldkamp, A. (2019). Predictors of stunting with particular focus on complementary feeding practices: A cross-sectional study in the Northern Province of Rwanda. Nutrition, 11-18. https://doi.org/10.1016/j.nut.2018.07.016

Vilcins, D., Sly, P. D., \& Jagals, P. (2018). Environmental risk factors associated with child stunting: A systematic review of the literature. Annals of Global Health, 84(4), 551-562. https://doi.org/10.29024/aogh.2361

Vollmer, S., Harttgen, K., Subramanyam, M. A., Finlay, J., Klasen, S., \& Subramanian, S. V. (2014). Association between economic growth and early childhood undernutrition: Evidence from 121 Demographic and Health Surveys from 36 low-income and middle-income countries. The Lancet Global Health, 2(4), e225-e234. https://doi.org/10.1016/ S2214-109X(14)70025-7

Vorster, H. (Esté) H. (2010). The link between poverty and malnutrition: A South African perspective. Health SA Gesondheid, 15(1), 1-6. https://doi.org/10.4102/hsag.v15i1.435

WHO. (2014a). Global Nutrition Targets 2025: Stunting Policy Brief. World Health Organization. Geneva.

WHO. (2014b). WHA Global Nutrition Targets 2025: Stunting Policy Brief. World Health Organization. Geneva.

Worku, B. N., Abessa, T. G., Wondafrash, M., Vanvuchelen, M., Bruckers, L., Kolsteren, P., \& Granitzer, M. (2018). The relationship of undernutrition / psychosocial factors and developmental outcomes of children in extreme poverty in Ethiopia. 1-9. https://doi. org/10.1186/s12887-018-1009-y

World Bank. (2016). World Bank investing in Early Years Brief. World Bank. Washington, DC.

Zaif, R. M., Wijaya, M., \& Hilmanto, D. (2017). Hubungan antara Riwayat Status Gizi Ibu Masa Keha milan dengan Pertumbuhan Anak Balita di Kecamatan Soreang Kabupaten Bandung [Relationship between History of Maternal Nutritional Status during Pregnancy and Growth of Toddler Children in Soreang District, Bandung Regency]. Jurnal Sistem Kesehatan, 2(3), 156-163. https://doi.org/10.24198/jsk.v2i3.11964 